\title{
LaporanLiteratur Review
}

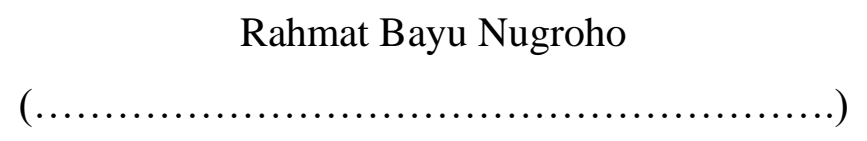

Program StudiPendidikan IPS FKIP ULM

1810128310016

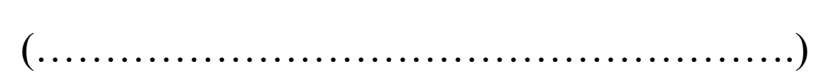

\section{Karya ilmiah yang di review}

Anis, M. Z. A., Putro, H. P. N., Susanto, H., \&Hastuti, K. P. (2020). Historical Thinking Model in Achieving Cognitive Dimension of Indonesian History Learning.PalArch's Journal of Archaeology of Egypt/Egyptology, 17(7), 7894-7906.

\section{Ringkasan Artikel}

\section{Pemikiran Historis Model Pencapain Dimensi Kognitif Pembelajaran Sejarah}

Penddikan sejarah berdasarkan kontruktivisme setuju bahwa siswa dan guru di berikan pengetahuan tentang metode sejarah yang di kenal dengan pemikiran sejarah ( Seixas, 2007). Pandangan ilmu sejarah yang telah di definisikan oleh sebagain para ahli dalam maupun luar mengenai dengan dua pandangan intelektual keterampilan dan keterampilan.

Setiap pembelaran yang di lakukan di SMA, pengajar di tuntut agar mengajar secara konvesional serta tidak mengunakan pemngembangan intelektual, guru sejarah cenderung membiasakan pembelajaran denagan selalu menekankan peserta didik dalam konteks menghafal seperti dengen mengingat nama tokoh pejuang, tangal dan juga tahun sehingga peserta didik jauh dari proses kesadaran. ( Fatimah et., 2020).

Pemikiran di dalam sejarah menuntut agar terhadap sikap kritis kepada fakta, mendefisinikan, dan megaitkan peristiwa masa kini dan masa lalu. ( ginting dkk., 2020). 
Dari berbagai tema yang telah di definisikan di dalam sejarah menunjukan hasil yang amat berbeda dari satu sama lain. Dengan kata lain peserta didik belum bisa menyelesaiakan sebuah masalah dan efektifitas mendapatkan hambatan.

\section{Relevansi jenis/metode evaluasi yang dibahas}

Pada dasarnya dari revew yang telah di uraikan di atas bawasanya pengetahuan tentang sebuaah pemikiran sejarah sampai saat ini sebagian besar guru maupun sejarawan hanya saja sedikit memberikan waktu untuk berdiskusi mengenai tentang teori apa yang telah mereka perbuat. Di harapkan kepada lulusan yang amat rutin mampu meidentifikasi secara epistemologis dan secara teori naratif. Sehingga menciptakan sebuah perubahan yang mana menjadikan keperbedaan yang berbeda dari sebelumnya.

Dapat di lihat bahwa minat dan bakat peserta didik semakin meningkat jadi sejarah juga harus mempunyai motifasi dengen meneliti masalah yang di hadapi dengan demikian pemikiran sejarah di definisikan dengan berbagai persperktif, keterampilan dengan berpikir sejarah berimbas seperti sejarawan dalam melakukan melakukan sejarah. Dan juga merancang pembelajaran sejarah dan juga di harapakan membuat dan melakukan evaluasi. Oleh sebab itu pemikiran di dalam sejarah di tuntut pada sikap, berpikir kritis dan menekankan terhadap fakta.

Dari berbagai kajian yang telah di kaji mempunya hasil yang beda dari satu sama lain dengan demikian peserta didik belum dapat menyelesaiakn sebuah masalah dan efektifitas terhadap hambatan.

Oleh karena itu kita di haruskan berpikir konstruktif supaya kita mengetahui kecerdasan sudah sejauh mana, berpikir dengan mengunakan kecerdasan berdasarkan pengalaman dalam artian konstruktif bisa di artikan sejauh mana orang tersebut bisa melakukanya dengan demikian menggunakan pemikiran otomatis dapat menyelesaiakan sebuah masalah dalam kehidupan sehari berdasarkan pengalaman yang pernah di alami.

Dengan mengunakan pemikiran konstruktif di harapkan seseorang dapat mengatasi sikap, dan juga prilaku, sehingga tidak berlebihan terhadap satu sama lain, dengan demikian sebuah kemampuan individu terhadap menyelesaikan masalah dan dapat menyelesaiakan di dalam kehidupan bahkan ketika individu berada di bawah tekanan. 


\section{Simpulan}

Terbentuknya dalam sebuah peimkiran sejarah yang di kira sudah di angap sangat penting ternyata kurang tersandar, yang membuat pengajar menyimpulkan bahwasanya membuat pendidik berupaya meneliti instrumen tersebut, yang di butuhkan dalam pelajran sejarah,jadi pada tahapan ini yang sangat di kembangkan ialah penilaian berpikir sejarah peserta didik yang berdominsi terhadap komponen kognitif, berupa factual dan actual,

Oleh karena itu kemungkinan pada pengajaran sejarah mendapatknna sebuah solusi terhadap di mensi kognitif yang lebih actual, dengan adnya penelitian tersebut mengakomodasi terhadap peserta didik, dosen dan juga guru, dapat mengakomodasi pengalaman dan juga masalah pada diri mereka,dengan melakukan cara ini kemungkinan dapat menyelesaikan pemecahan masalah yang komprehensif dan amat memungkinkan.

\section{Referensi}

Anis, M. Z. A., Putro, H. P. N., Susanto, H., \&Hastuti, K. P. (2020). Historical Thinking Model in Achieving Cognitive Dimension of Indonesian History Learning.PalArch's Journal of Archaeology of Egypt/Egyptology, 17(7), 7894-7906.

APA Fatimah, F, Rajiani, S., \& Abbas, E. (2020). Cultural and individual characteristics adopting computer supported collaborative learning during covid-19 outbreak: willingness or obligatory to accept technology?. Management Sciente Letters, 2020, 11.2: 373-378.

Ginting,A S., joebagio, H, \& Si, C,. D. (2020). A need analysis of history learning model to improve constructive thingking ability through scientific approach. International journal of Education and Social Sciense Research, 3(1), 13-18.

Seixas. P. ( 2007). A model of historical thingking. Education Philosophy and Theory, $49(6), 593-605$ 